\title{
Studies On the reform of College English teaching based on the combination of Micro course and Flipped classroom
}

\author{
AiQinghua \\ Nanchang Institute of Science \& Technology, Nanchang 330108,China
}

Key words: Micro course; flipped classroom; teaching reform; teaching mode

\begin{abstract}
With the rapid development of information technology and the Internet, the emergence of a number of new things. "Micro Courses" and "flip the classroom as a new teaching mode, and achieved good teaching effect in the process of foreign applications, the" micro curriculum "and" flip the classroom together, provide new opportunities for the reform and innovation of College English teaching, study of flipping the classroom to the micro course based on the teaching mode has an important significance to improve college students' learning efficiency.
\end{abstract}

\section{Introduction}

With the continuous progress and development of science and technology, widely use of intelligent mobile phone, computer, wireless network, there is a new demand for College English learning, the traditional teaching mode has been unable to meet the modern college students' learning motivation. In recent years, the rise of "micro course" and "flipped classroom" has brought a new way to the reform of College English teaching, It can make up for the shortage of traditional college English teaching mode with the development and application of high quality College English micro curriculum resources, and creating a diversified network platform, which can further stimulate students' English learning passion. Lead the students to learn English.

\section{Introduction of "Micro course" and "flipped classroom"}

With the continuous progress of science and technology, the network technology is constantly being applied to the education system, so in the field of education, a new teaching mode is presented, which takes video as the main carrier, the new curriculum model has been pursued by the majority of education, which has rich resources, bright scene, great practical potential. "Flipped classroom" is based on the teaching video provided by the teachers, the students watch and learn the content of the video before class. So there are a lot of similarities between "micro course" and "flipped classroom", all of which are based on video, and they are of great value in the teaching of College English. "Micro course" is mainly show the difficult and doubtful knowledge and teaching points in the courseware with a short video online, it includes not only the design of the curriculum, but also contains exercises. "Micro course" is the original 45 minutes to 90 minutes of teaching content concentrated in the 10 minute to 20 minutes of video, so that learners can focus on systematic learning. Because the micro course is short and pithy, so it can be integrated with various teaching modes, such as flipped classroom, mixed class etc.. The traditional teaching mode is the teacher in the classroom to teach students knowledge, knowledge of the review and extension in the class, the so-called "flipped classroom", is this a reversal process, teachers will provide the teaching video to the students, let the students to watch and self-study before class, then in the classroom knowledge points can be imparted in the form of group discussion, questions and answers. "Flipped classroom" has a strong interaction and autonomy, and it is to maximize the use of classroom time, which is the 
same as the micro classroom, and guide the students to actively participate in learning, "Flipped classroom" based on "micro course" can be formed by organic combination of the two. The basic process is as follows

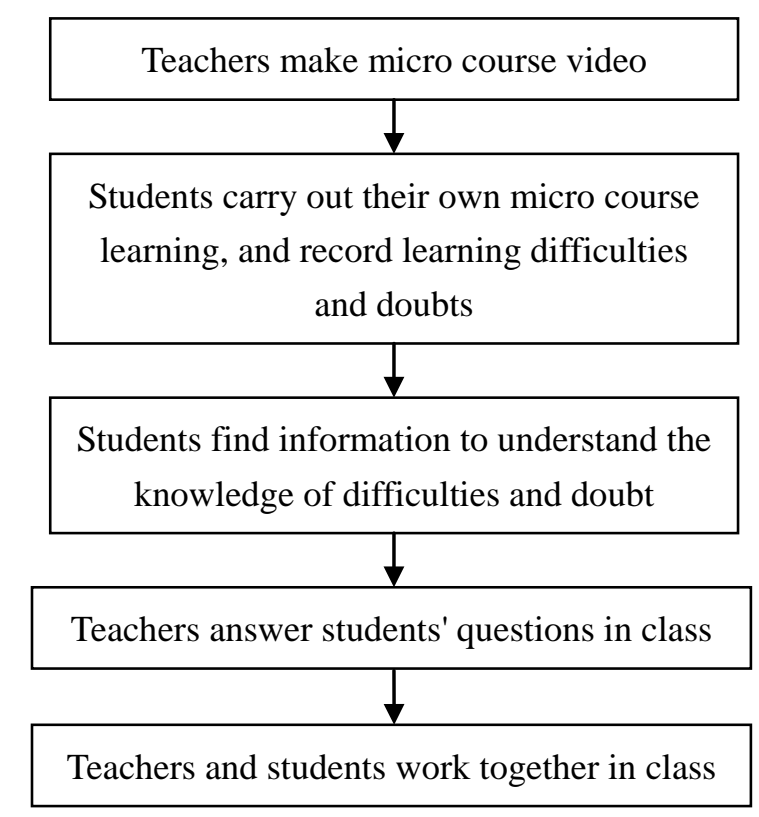

Fig.1 The basic flow chart of "flipped classroom" based on the "micro course"

\section{The significance of "flipped classroom" based on "micro course" in College English Teaching}

Help students to play a dominant role and improve their ability to learn independently. In the traditional college English teaching process, most of the time is the teachers "speaking", students only need to listen and make notes, and teachers do not concern themselves about whether the contents meet the needs of students, whether students can keep up with his own rhythm. In this kind of teaching system, students do not play the main role, it is difficult to play the initiative, so students' autonomous learning ability can not be effectively improved. In "flipped classroom" based on "micro curriculum", students need to look at the micro course before the course to complete the independent focus on the knowledge of learning, and to grasp their own progress according to their own situation, for example, in the process of watching the micro video teaching materials, students can be repeated playback some of the knowledge points that can't be understood, and make notes in class, in order to communicate with the teacher. In addition, students are not like before relying on the teacher, they should analyze the study situation and meet their own learning process, and the important points and difficulties should be summarized after the completion of their study of relevant information.

It can be seen that the "flipped classroom" teaching model based on the "micro course" can highlight the dominant position of students, and promote students to shift from passive learning to active learning, and help students to play the main role and improve the students' ability of autonomous learning.

Conducive to the conversion of the role of teachers and students and improve students' language skills. In the traditional college English teaching process, students listen a lot but practice very little, students can master the language knowledge well, but they can't use the spoken English. After a series of teaching mode innovation, this situation has been improved, but it has not been completely resolved. Based on the teaching mode of "flipped classroom", teachers change from the controller of the previous course to the guide of students' learning, students can realize the 
transformation of the students as the main body through the students' autonomous learning before class and full participation in classroom activities. It can effectively improve the level of students' language knowledge and language skills that the conversion of this role. Students can effectively improve the students' ability of oral expression by interacting with others in the classroom and discussing the problems they encounter in the process of autonomous learning. In addition, vivid teaching situation can greatly mobilize the enthusiasm of students.

Conducive to cultivating the excellent and helping the poor, implementation of hierarchical teaching mode. The "flipped classroom" based on "micro course" teaching model is applied to college English teaching process, which can achieve superior culture supplement teaching effect effectively and English teaching level. The traditional English teaching is in the form of large class teaching, teachers often can only take care of most of the learning level of secondary students, some students, whose learning ability is very strong or poor, can not be took into account, it is easy to make the teaching process become mediocre. The flipped classroom model based on the "micro course" can make up for this shortcoming, let students learn independently through the network video after enrichment, leak filled according to their own situation, which can effectively enhance students' learning level, and can realize the hierarchical teaching of College English, so that the overall level of College English has been effectively improved, and it can play a positive role for every college student development.

Building network platform, help to improve the efficiency of College English Teaching, The biggest advantage of the flipped classroom is that, it can make full use of the network platform, according to the students' favorite way of English teaching, improve teaching effect. Teachers can create a network interactive platform, upload some videos, lesson plans, relevant cases and information on the platform, so that students can see these resources and learn knowledge according to their own needs. Formed by concentrated course video dapper, infectious, it is easy for students to be brought into the concrete situations, which can effectively improve the students' interest in learning. When meeting any problems in the process of learning, students can take the initiative to think, so as to find the right answer, rather than relying on the teacher to answer. In short, the establishment of the network platform is a comprehensive and independent teaching mode, which has some significance to improve the teaching of College English.

\section{The application of "micro course" in College English "flipped classroom"}

"Micro course" is suitable for the teaching of "flipped classroom". The main characteristics of the micro course is short and capable, comprehensive, focused. It will be combined with the flipped classroom, so that students watch the video before class, it can cultivate students' autonomous learning ability by learning the elements in advance, students will be changed from passive listening to active preview and thinking before class, and through the training and testing way to master the important knowledge, to master the knowledge points to the classroom in the preparation process, resolve their doubts through teacher-student interaction and student group discussion etc.. In the course of teaching, we should take the students as the main body and break the traditional teaching mode. It is helpful to cultivate students' divergent thinking and critical thinking, to enhance students' sense of cooperation and team spirit, to improve students' ability to analyze and solve problems by students' independent learning and participate in interactive activities.

"Micro course" design in the "flipped classroom" teaching. There are some differences in the English proficiency of Chinese College students, therefore, teachers and design teams should grasp the overall situation of students' English learning, design and manufacture of micro video, according to the difficulty of the teaching materials of different majors. In the process of making 
micro courses, there are several aspects worthy of attention.

First of all, College English "micro course" should be presented in different ways in different ways. Now, after the reform of College English teaching, many colleges and universities adopt stratified teaching, but some colleges and universities still adopt the teaching mode of class division. In "Micro course", it requires different production according to the different types of courses. For example, in intensive micro courses, we should focus on the important words and sentences, but also highlight the understanding of the entire article; in listening and speaking micro courses, we need to focus on the topic of the unit, focusing on the development of English listening and oral English skills; in writing and translation courses, we need to pay attention to the cultivation of micro training and writing and translation skills.

Secondly, due to the use of different college English textbook version is not the same, making the micro course design should be closely combined with the teaching content, so as to enable students to preview the new curriculum content, flip type learning reference basis, to better grasp the important points of knowledge.

\section{Conclusion}

In a word, through the teaching reform on College English, teaching mode based on the combination of "micro curriculum" and "flipped classroom" has injected a fresh to College English reform, which brings vitality to the College English classroom. Whether the relationship between teachers and students, or teaching methods, teaching ideas have undergone major changes. But before the flipped course based on "micro course", the teaching team and the design team should be able to make use of high-quality teaching resources to design high-quality of micro courses, and also requires students to actively cooperate with the teacher's teaching methods. Through the continuous improvement of "micro course" and "flipped classroom", the teaching effect of College English will be significantly improved.

\section{Reference}

[1] Li Huiju. Study on College English teaching model reform with the combination of OBE and flipped classroom [J]. Journal of Changchun Institute of Technology (Social Sciences Edition), No.04, (2016), p.132-135.

[2] Ren Liya. Application of micro course in Higher Vocational Mathematics Teaching [J], Ability and Wisdom, Vol.29, (2016), p.13

[3] Deng Lihong. Experimental research on the application of flipped classroom teaching model in College English teaching [D]. Guangxi Normal University, (2016)

[4] Xingyuan.. design and development of flipped classroom interactive micro course based on SPOC[D], Hebei Normal University, (2016)

[5] Yin Yongqi, Gao Lu, Rao Shengqi, Yang Zhenquan, Fang Weiming. The micro course teaching design and application Under the background of educational informationization[J]. Science \& Technology Vision, Vol.33, (2015), p.16,54.

[6] Xing Qianfei. "High school information technology foundation" course teaching of micro course design and Application Research of [D]. Guangxi Teachers Education University, (2015)

[7] Wang Hongyu. Application Research of micro course in Higher Vocational Education "mechanical drawing" [D]. Guangdong Polytechnic Normal University, (2015) 
[8] Analysis of the current situation and Countermeasures of the application of in the teaching of junior middle school. [D]. Zhejiang Normal University, (2015)

[9] Zhao Jing. The influence and challenge of online courses on college curriculum and teaching [D]. Shenyang Normal University, (2015)

[10] Zhou Ting, Tan Jiayi, Feng Kai, etc. A new type of learning resource package under the background of micro course: Nano course [J]. The Chinese Journal of ICT in Education .Vol.23 , (2014), p.44-46.

[11] Qiu Lingtao. College English Teaching in the teaching of micro class [J]. Overseas English, Vol.19, (2014), p.61

[12] Zhang Lingzhi. Study on the application of micro course in Higher Vocational Education[J]. Chinese Vocational and Technical Education, Vol.26, (2014), p.70-72.

[13] Wang Xinguo, Qin Zhiwei, Zhang Yongqiang. The exploration and practice of the micro course resources construction in Colleges and universities[J]. Higher Agricultural Education, No. 06, (2014), p.59-61.

[14] Wang Aiyang. "Mold equipment" course informatization instructional design based on flipped classroom concept [J]. Management and technology of small and medium-sized enterprises, No.05, (2014) , p.251-252.

[15] Xu Zhengtao. Design and Practice Research on the model of micro course construction in primary and secondary schools [D]. Southwestern University Moodle. (2014)

[16] Wang Laiyin. The micro class teaching effectiveness research [D]. Yangzhou University, (2014) 